\title{
Teaching Reading Comprehension by Using the Cloze Strategy: The Case of One Islamic Private Junior High School
}

\author{
Meidiana Eka Putri \\ Matrik Learning Center, Palembang \\ meidianaekaputri@yahoo.com
}

\begin{abstract}
The aim of this study was to find out whether or not there was a significant difference on students' reading comprehension achievement between the students who were taught by using Cloze Strategy and those who were taught by using the teacher's method at an Islamic private junior high school in Palembang. Quasi experimental design was applied in this study. The sample was chosen by using a convenience sampling technique. Eighty one of the eighth grade students of an Islamic private junior high school in Palembang were selected as the sample of the study. The reading test was used as the instrument in collecting the data which consisted of recount and narrative texts. The test was administered twice as the pretest and post test for both experimental and control groups. In this study, the independent t-test was applied to analyze the data. The result of this study revealed that, there was a significant difference on students' reading comprehension achievement between the students who were taught by using Cloze Strategy and those who were taught by using the teacher's method.
\end{abstract}

Keywords: Cloze strategy, reading comprehension, teaching reading

\section{Introduction}

Reading is one of the language skills which is very important for the English learners to learn (Erlina et al., 2019; Nazurty et al., 2019). According to Komiyama (2009), reading is an important skill for English learners since it supports the development of overall proficiency and provides access to crucial information at work and at school. Through reading, students can get useful information for their life and expand their knowledge. Furthermore, Zuchdi (2007) states that reading is a form of communication process to get information faster from the writer to the reader. Therefore, reading is a way to get information and knowledge. Harmer (2000) lists some reasons which make reading in English important to teach. First, reading is for language acquisition. Harmer (2000) claims that reading helps students get the idea or know what expression is used in certain occasion. Secondly, reading can be a model for future writing (Astrid et al., 2019; Erlina et al., 2019; Makmur et al., 2016; Soma, Mukminin, \& Noprival, 2015). Many kinds of knowledge and information can be gained through reading and what students have read can inspire them to write. Finally, it is very important to practice the skills of reading. When reading becomes an activity which students usually do especially in the classroom, they will have better reading skills (Erlina et al., 2019; Marzulina et al., 2018; Marzulina et al., 2019).

In Indonesia, reading literacy still becomes a problem for students. There are some studies which show that literacy in Indonesia is decreasing. For example, the data by UNESCO Institute for Statistics (UIS) showed that the number of illiterate adults were about 13 millions of 
people (UNESCO, 2011). Besides, the result of Progress in International Reading Literacy Study (PIRLS) showed that students' reading literacy in Bahasa Indonesia was low (PIRLS, 2011).

In fact, although reading skill gets the most attention in English teaching in Indonesia, reading English is still considered difficult for many people (Abrar et al., 2018; Mukminin, Ali, \& Ashari, 2015; Mukminin et al., 2019). Based on the research, Lyon (2010) states that as the most prioritized skill, many students in Indonesia assume that reading skill is very difficult. From the result of the research, it was concluded that some difficulties in reading skill emerged because of some different reasons such as lack of vocabulary, learning support, language knowledge, pronunciation ability, reading skills, interest, and reading motivation. All of them make reading seems to be the difficult skill in learning English for the students. One of the ways to solve the students' difficulties in reading is by choosing the appropriate strategy in teaching reading. To choose the appropriate strategy for teaching reading to students is very important. According to Kaniuka (2010), if the teacher chooses the inappropriate teaching strategy to the students, the teaching and learning process will not be effective and the difficulties of learning English especially reading skill will emerge. Crede and Kuncel (2008) illustrated that in junior high schools there are many students which are in their transition years who experience confusion and have less motivation towards learning at school. They have unwillingness to learn and lack of motivation which certainly decrease the level of students' achievement. Therefore, the teachers are demanded to be smart in determining the appropriate strategy in teaching and learning process (Astrid et al., 2019). From the informal interview to one English teacher of an Islamic private junior high school in Palembang, I found that the students faced difficulties in comprehending texts. Some problems were found in which the students felt bored in reading long texts. Then, they were difficult in finding topic and information from the text as they had lack of vocabulary. Besides, the students were difficult to comprehend the text because they did not understand what they read. It means that the students thought that English was too difficult to learn. The fact also showed that students' reading achievement in comprehending the English text was very low. Based on the data, there were only few students who passed the minimum score criteria $(K K M)$ where the established minimum score was 75 .

Furthermore, I got the information that in the classroom, the teacher usually asked the students to read aloud and then let them find out difficult words. After finding out some difficult words, the teacher asked the students to translate the whole text and asked them to answer the questions individually. Based on the procedures, it can be stated that the method which was used by teacher of the school was grammar translation method. According to Cook (2003), grammar translation method is used where grammatical rules are explained to the students in their own language and vocabulary lists are learned with translation equivalents. Students learn the vocabulary and grammatical rules from the teacher or from a grammar book and practice those rules by doing translation exercises (Marzulina et al., 2019).

Considering to the problems in reading, it is necessary for teachers of English to find out the appropriate strategy that can encourage their students' ability in reading comprehension. One type of the strategy that can be used is Cloze Strategy. The Cloze Strategy offers help in developing scanning as one of reading skills which is very often neglected in both first and second language reading (Rye, 1999). Based on the previous problems I have described, I was interested in conducting the research which aimed at investigating whether or not there was significant difference on students' reading comprehension achievement between the students who were taught by using Cloze strategy and those who were not.

Ta'dib: Journal of Islamic Education • Volume 25, Number 1, June 2020 


\section{Literature Review}

\section{Concept of teaching reading comprehension}

Teaching is guiding and facilitating learning which enables the students to learn and sets condition for learning (Brown, 2007). It means that the students must be active in learning process, because teaching is the ability by which the teacher guides and gives lesson by setting condition to create effective learning activities. In addition, teaching is an activity to transfer the knowledge to the students. Thus, teaching is an interactive process between the teacher and the students and among those students themselves. Comprehension is a strategic process by which readers construct or assign meaning to a text by using the clues in the text and their own prior knowledge (Cooper, 2000). The readers need to comprehend the reading text and understand what they read because comprehending a reading text is an active thinking process that depends not only on comprehension skills but also on the readers' experiences and prior knowledge. In order to comprehend the reading text, the readers do not only transfer the printed symbol from page to the brain but also have to comprehend the content of what the they read.

Reading comprehension is the degree of process to understand a text. Goodman (2000) states that reading comprehension is the process of simultaneously extracting and constructing texts through interaction. When we pick up the newspaper and read about for example the latest election results, or grab a novel off the shelf of the local bookstore, actually we are using our reading comprehension skills to gather information from the text. Besides, according to Richards and Renandya (2002), reading for comprehension is the primary purpose for reading for main ideas and exploring the organization of a text. Thus, reading comprehension is the interaction between a reader and a writer where the reader tries to reconstruct the writer's message. When students are required to read, the students do not only read the text but also they have to comprehend the written information or message from the text.

\section{Concept of Cloze strategy}

According to Brown (2007), the word Cloze was coined by educational psychologists to capture the gestalt psychological concept of closure that is the ability to fill in gaps in an incomplete image and supply omitted details. The Cloze strategy assesses the match between a reader and particular text. It will not give a reading level for the reader, but it will provide an indication of how much support the reader needs to comprehend the specific text. Teachers construct a Cloze text by taking excerpts from a storybook, an information book or content-area textbook that students have read. Cloze Strategy usually requires a minimum of two paragraphs in length. According to Duke and Pearson (2001), Cloze strategy was originally developed to assess student's use of strategies and it is a very effective way to teach reading comprehension. Cloze passages are written texts from which words or letters have been deleted. When completing a Cloze text, children practice by using effective strategies. The purpose of Cloze strategy is first, to help students read for meaning through prediction and discussion because it is very effective procedure when it is used for reading for specific content area, and secondly, to help children determine how much they know the content of the text before reading it and how much they have learned after reading that text. 


\section{Practical guides of Cloze strategy}

According to Mather (2002), there are several practical guides for the implementation of Cloze Strategy. They are as explained as follows.

Phase 1: Presentation and preparation, in pre-reading activities, the teacher motivates the students and builds their students' background knowledge. The teacher must provide short practice sessions. Then, the teacher must work with the students and model how the exercises are completed to construct a reading passage.

Phase 2: Preview and completion, in this stage, the teacher asks the students to read the passage three times. During the first reading, the students can gain an overview of the material and they are required to fill in the blanks in the reading passage. In the second reading, the students are expected to fill in all of the blanks. For the third reading, the students are asked to check if the responses make sense. During the second and third process of reading, the students may work in pairs or small group.

Phase 3: Follow-up, the most important step is the follow-up conference. The teacher must discuss with the students about their choices, review other acceptable alternatives, and ask the students to explain why they choose a particular response. If needed, the teacher should discuss specific context clues that are found around the blank and assist the students in word selection. As a final step, the teacher must ask the students to compare their responses with the original text.

\section{Methods}

\section{Research design, research site and participants}

This study was conducted by using quasi-experimental research method because I wanted to find out the significant difference on students' reading comprehension achievement between the students who were taught by using Cloze strategy and those who were taught by using the teacher's method to the eighth grade students of an Islamic private junior high school in Palembang. I divided the sample into two groups, experimental and control group. The students in each group were asked to do pre-test, and post-test. In the experimental group, the students were taught by using Cloze Strategy. Meanwhile, in the control group, the students were treated by using the teaching method that was usually used by the teacher at that school. The study was done at one Islamic private junior high school in Palembang. The population consisted of 242 eighth grade students from six classes. In order to select the sample, I used convenience sampling technique. A convenience sample is a group of individuals who are conveniently available for the study (Fraenkel \& Wallen, 2012). the sample was chosen based on the convenience sampling technique where the teacher at that school assigned two classes which comprised of 81 students.

\section{Data collection and analysis}

The data were collected by using a reading test in the form of multiple choices. For the reading materials included in the test, I used two types of text, recount and narrative text. These two types of text were in line with the syllabus for the eighth grade. Next, I tried out the reading test to non sample students in SMP Nurul Amal Palembang in order to check the validity of the 
reading test items quantitatively. Based on the results of the reading test tryout, 31 items were valid. The items were considered to be valid since $r$-value was higher than r-table $(0.355)$. The distribution of reading comprehension test items is shown in Table 1.

Table 1. The distribution of reading comprehension test

\begin{tabular}{|c|c|c|c|}
\hline & Sub Variables & Indicators & Item Number \\
\hline \multirow{7}{*}{$\begin{array}{l}\text { To measure } \\
\text { students' } \\
\text { reading } \\
\text { comprehension } \\
\text { achievement by } \\
\text { using Cloze } \\
\text { strategy }\end{array}$} & Detail & $\begin{array}{l}\text { Students are able to find out the } \\
\text { details in the text }\end{array}$ & $\begin{array}{l}1,6,8,13,16,20,21,23,24, \\
25,28,31\end{array}$ \\
\hline & Reference & $\begin{array}{l}\text { Students are able to identify the } \\
\text { people involved in the text }\end{array}$ & $4,7,10,15,26,27$ \\
\hline & Sequence & $\begin{array}{l}\text { Students are able to find out the } \\
\text { sequences or chronological series } \\
\text { of the text. }\end{array}$ & 2,22 \\
\hline & Vocabulary & $\begin{array}{l}\text { Students are able to identify } \\
\text { (predict or guess) the meaning of } \\
\text { words. }\end{array}$ & $12,14,19$ \\
\hline & Main idea & $\begin{array}{l}\text { Students are able to skim for } \\
\text { main idea and analyze the text }\end{array}$ & $5,11,29,30$ \\
\hline & Cause-effect & $\begin{array}{l}\text { Students are able to determine } \\
\text { causal effect relationship in the } \\
\text { text }\end{array}$ & 3,9 \\
\hline & Inference & $\begin{array}{l}\text { Students are able to interpret } \\
\text { events and infer implicit } \\
\text { information }\end{array}$ & 17,18 \\
\hline Total & & & 31 items \\
\hline
\end{tabular}

In this study, the treatment was done in six meetings to get maximal results from the strategy that I had applied in the classroom. The treatment was given to the experimental group. I decided the reading materials for the research treatment. The reading materials for the research treatment is listed in Table 2.

Table 2. The reading materials for the research treatment

\begin{tabular}{ccc}
\hline No & Reading Text Title & Time \\
\hline 1 & The Little Tree & $2 \times 40$ \\
2 & Aji Saka and Dewata Cengkar & $2 \times 40$ \\
3 & My Smartest Parrot & $2 \times 40$ \\
4 & My Experience & $2 \times 40$ \\
5 & Sangkuriang and Takuban Perahu Mountain & $2 \times 40$ \\
6 & Abu Nawas & $2 \times 40$ \\
7 & Maya Ghazali & $2 \times 40$ \\
8 & A bear and a rabbit & $2 \times 40$ \\
9 & Botanical garden & $2 \times 40$ \\
10 & Cinderella & $2 \times 40$ \\
\hline
\end{tabular}


In this study, independent t-test was used to measure a significant difference of the students' post test scores between the students who were taught by using Cloze strategy and those who were taught by using the strategy that was usually used by the teacher of one Islamic private school in Palembang. Before using independent sample T-test, all data from students' pre-test and post test scores were analyzed to find out whether the data were normal and homogeneous.

\section{Findings}

\section{Students' pretest and post test scores in the control group}

The data were gathered from the reading test. Tabel 3 presents reading comprehension scores in the control group. Based on the result of the pretest scores, there were one student getting $47.5(2.5 \%)$, two students getting $50(5.0 \%)$, one student getting 52.5 (2.5\%), two students getting $55(5.0 \%)$, two students getting $57.5(5.0 \%)$, four students getting $60(10.0 \%)$, two students getting $62(5.0 \%)$, one student getting $62.5(2.5 \%)$, seven students getting 65 $(2.5 \%)$, two students getting $67.5(5.0 \%)$, three students getting $70(7.5 \%)$, one student getting 72 ( $2.5 \%)$, six students getting 72.5 ( $15.0 \%)$, three students getting 75 ( $7.5 \%)$, two students getting 77.5 ( $5.0 \%)$ and one student getting $82.5(2.5 \%)$.

Table 3. The distribution of data frequency of students' pretest scores in the control group

\begin{tabular}{ccc}
\hline Score & Frequency & Percentage \\
\hline 47.5 & 1 & 2.5 \\
50 & 2 & 5.0 \\
52.5 & 1 & 2.5 \\
55 & 2 & 5.0 \\
57.5 & 2 & 5.0 \\
60 & 4 & 10.0 \\
62 & 2 & 5.0 \\
62.5 & 1 & 2.5 \\
65 & 7 & 17.5 \\
67.5 & 2 & 5.0 \\
70 & 3 & 7.5 \\
72 & 1 & 2.5 \\
72.5 & 6 & 15.0 \\
75 & 3 & 7.5 \\
77.5 & 2 & 5.0 \\
82.5 & 1 & 2.5 \\
Total & 40 & 100.0 \\
\hline
\end{tabular}

Meanwhile, based on the result of the post test scores, there was one student getting $47.5(2,5 \%)$, four students getting $50(10 \%)$, three students getting $52.5(7.5 \%)$, one student getting $55(2.5 \%)$, one student getting $57.5(2.5 \%)$, six students getting 60 (15\%), six students getting $62.5(15 \%)$, six students getting $65(12.5 \%)$, two students getting $67.5(5 \%)$, four students getting $70(10 \%)$, four students getting 72.5 (10\%), two students getting $75(5 \%)$, and one student getting 80 $(2.5 \%)$. The results are presented in the following Table 4. 
Table 4. The distribution of data frequency of students' post test scores in the control group

\begin{tabular}{ccc}
\hline Score & Frequency & Percentage \\
\hline 47.5 & 1 & 2.5 \\
50 & 4 & 10.0 \\
52.5 & 3 & 7.5 \\
55 & 1 & 2.5 \\
57.5 & 1 & 2.5 \\
60 & 6 & 15.0 \\
62.5 & 6 & 15.0 \\
65 & 5 & 12.5 \\
67.5 & 2 & 5.0 \\
70 & 4 & 10.0 \\
72.5 & 4 & 10.0 \\
75 & 2 & 5.0 \\
80 & 1 & 2.5 \\
Total & 40 & 100.0 \\
\hline
\end{tabular}

\section{Students' pretest and post test scores in the experimental group}

From the analysis of the students' pretest scores in the experimental group, it was found that there was one student getting $50(2.4 \%)$, two students getting 55 (4.9\%), thirteen students getting $60(31.7 \%)$, eight students getting $62.5(19.5 \%)$, two students getting $65(4.9 \%)$, one student getting 67.5 (2.4\%), eight students getting 70 (19.5\%), two students getting 75 (4.9\%), three students getting 80 (7.3\%), and one student getting $82.5(2.4 \%)$. The data were listed in Table 5 .

Table 5. The distribution of data frequency of students' pretest scores in the experimental group

\begin{tabular}{ccc}
\hline Score & Frequency & Percentage \\
\hline 50 & 1 & 2.4 \\
55 & 2 & 4.9 \\
60 & 13 & 31.7 \\
62.5 & 8 & 19.5 \\
65 & 2 & 4.9 \\
67.5 & 1 & 2.4 \\
70 & 8 & 19.5 \\
75 & 2 & 4.9 \\
80 & 3 & 7.3 \\
82.5 & 1 & 2.4 \\
Total & 41 & 100.0 \\
\hline
\end{tabular}

Based on the result of the analysis of students' post test scores in the experimental group, there was one student getting 55 (2.4\%), two students getting 60 (4.9\%), one student getting 62.5 (2.4\%), four students getting 65 (9.8\%), six students getting 67.5 (14.6\%), five students getting $70(12.2 \%)$, seven students getting $72.5(17.1 \%)$, five students getting $75(12.2 \%)$, three students getting $77.5(7.3 \%)$, one student getting 80 ( $2.4 \%)$, two students getting 82.5 (4.9\%), one student getting $85(2.4 \%)$ and three students getting $87.5(7.3 \%)$. The data are listed in Table 6. 
Table 6. The distribution of data frequency of students' post test scores - experimental group

\begin{tabular}{ccc}
\hline Score & Frequency & Percentage \\
\hline 55 & 1 & 2.4 \\
60 & 2 & 4.9 \\
62.5 & 1 & 2.4 \\
65 & 4 & 9.8 \\
67.5 & 6 & 14.6 \\
70 & 5 & 12.2 \\
72.5 & 7 & 17.1 \\
75 & 5 & 12.2 \\
77.5 & 3 & 7.3 \\
80 & 1 & 2.4 \\
82.5 & 2 & 4.9 \\
85 & 1 & 2.4 \\
87.5 & 3 & 7.3 \\
Total & 41 & 100.0 \\
\hline
\end{tabular}

\section{The descriptive statistics of the students' pretest and post test scores in the control group}

In the descriptive statistics, the total sample $(\mathrm{N})$, minimum and maximum scores, mean score, and standard deviation were analyzed. The scores were got from pretest and post test scores in the control group and pretest and post test scores in the experimental group. From the result of the descriptive statistics analysis of students' pretest scores in the control group, it was found that the total number of sample was 40 students. The minimum score was 47.50 , the maximum score was 82.50, the mean score was 65.525 and the score of standard deviation was 8.36809. The data are listed in Table 7.

Table 7. The descriptive statistics of students' pretest scores in the control group

\begin{tabular}{cccccc}
\hline & N & Min & Max & Mean & Std. Deviation \\
\hline $\begin{array}{c}\text { Pretest } \\
\text { Score }\end{array}$ & 40 & 47.50 & 82.50 & 65.5250 & 8.36809 \\
\hline
\end{tabular}

Based on the descriptive statistics analysis of students' post test scores, it was found that the total number of students was 40 . The minimum score was 47.50 , the maximum score was 80.00 , the mean score was 62.8125 , and the standard deviation was 8.14900 . The data were listed in Table 8.

Table 8. The descriptive statistics of students' post test scores in the control group

\begin{tabular}{cccccc}
\hline & N & Min & Max & Mean & Std. Deviation \\
\hline $\begin{array}{c}\text { Posttest } \\
\text { Score }\end{array}$ & 40 & 47.50 & 80.00 & 62.8125 & 8.14900 \\
\hline
\end{tabular}


The descriptive statistics of students' pretest and post test scores in the experimental group

From the result of descriptive statistics analysis on students' pretest scores in the experimental group, it was found that the total number of students was 41 . The minimum score was 50.00, the maximum score was 82.50, the mean score was 65.12 , and the score of standard deviation was 7.39407. The data are listed in Table 9.

Table 9. The descriptive statistics of students' pretest scores in the experimental group

\begin{tabular}{cccccc}
\hline & N & Min & Max & Mean & Std. Deviation \\
\hline $\begin{array}{c}\text { Pretest } \\
\text { Score }\end{array}$ & 41 & 50.00 & 82.50 & 65.1220 & 7.39407 \\
\hline
\end{tabular}

Meanwhile, from the result of the descriptive statistics analysis on students' post test scores in the experimental group, it was found that the total number of students was 41 . The minimum score was 55.00, the maximum score was 87.50, the mean score was 72.1951 , and the score of standard deviation was 7.60746. The data are listed in Table 10.

Table 10. Descriptive statistics of students' posttest scores in experimental group

\begin{tabular}{cccccc}
\hline & N & Min & Max & Mean & Std. Deviation \\
\hline $\begin{array}{c}\text { Posttest } \\
\text { Score }\end{array}$ & 41 & 55.00 & 87.50 & 72.1951 & 7.60746 \\
\hline
\end{tabular}

The result of the significant difference of the students' post test scores between the students who were taught by using Cloze strategy and those who were taught by using the strategy that was usually used by the teacher at the school

In this study, independent t-test was used to measure a significant difference of the students' post test scores between the students who were taught by using Cloze Strategy and those who were taught by using the strategy that was usually used by the teacher of one Islamic private school in Palembang. From the result of the analysis, it was found that the p-output was 0.000 and the t-value was 5.358. Since the p-output was lower than 0.05 level and the t-value was higher than critical value of t-tabel (1.9905), it can be stated that there was a significant difference on students' reading comprehension achievement who were taught by using Cloze Strategy compared with the students who were taught by using the method that was usually used by teacher of the school. The result of the analysis is listed in Table 11. 
Table 11. The result of Independent Sample T-Test

\begin{tabular}{ccccc}
\hline & \multicolumn{4}{c}{ Independent Sample t-Test } \\
\hline $\begin{array}{c}\text { Cloze strategy } \\
\text { and strategy that } \\
\text { usually used by } \\
\text { teacher }\end{array}$ & T & Df & Sig. (2-tailed) & Ho \\
\hline & 5.358 & 79 & 0.000 & Rejected \\
\hline
\end{tabular}

\section{Discussion}

Based on the research findings, some interpretations were made as follows; first, I assumed that the students in one Islamic private junior high school in Palembang needed a new treatment to increase their ability in reading comprehension. There are some reasons why reading text is important to increase students' ability. Harmer (2000) states that most of students want to be able to read the text in English for their study, career or simply for pleasure. The more the students read, the better reading ability they will have. By reading a lot, students have more opportunities to study language aspects, namely grammar, vocabulary, punctuation, and get the way to construct sentences, paragraphs and texts. It means that when the students read, they do not only improve their reading skill but also increase their understanding of language aspects (Mukminin et al., 2018; Nazurty et al, 2019).

Second, when I applied Cloze Strategy in the experimental group, most of students felt confused about the implementation of the strategy. After explaining the procedure of the strategy, the students felt interested in that strategy. According to Raymond (2002), this Cloze Strategy is incredibly useful in reading instruction because it can be easily conducted by every teacher and it can also provide valuable reading comprehension information. Moreover, based on my research, the Cloze Strategy helped the students determine how much they knew about the content before reading and how much they have learned after reading. In line with this, Chatel (2011) states that the lessons that use the Cloze procedure can help teachers to expand their students' use of language structure, meanings, and background knowledge to predict unknown or unfamiliar words. Third, the result of the mean score of students' post test scores in experimental group was 72.1951 meanwhile the in the control group was 62.8125 . Then, the maximum score in experimental group was 87.50 meanwhile in the control group was 80.00 . In other words, it can be seen that Cloze Strategy is one of appropriate strategies to teach reading comprehension skill. The results of this study was in line with the study conducted by Mintz (2009) who found that the students' scores after they were treated by using Cloze procedure was higher than the scores of the students who were taught by using GIST strategy at SMA Negeri I Depok.

Fourth, the result of independent t-test showed that the p-output was 0.000 and the t-value was 5.358. Since the p-output was lower than 0.05 level and the t-value was higher than critical value of t-table (1.9905), it can be stated that there was a significant difference on students' reading comprehension achievement taught by using Cloze strategy compared to those who were taught by using the strategy that was usually used by the teacher at the school. Finally, the teacher at the school just explained the text with traditional teaching method. A study conducted by Moenly (2009) found that one of the main reasons why students were unmotivated were 
caused by boredom where $66 \%$ of students were indicated to be bored in the class in every meeting. It happened because the students did not find interesting materials in the classroom and only listened to uninteresting lectures. Then, the students were difficult to comprehend the texts because the teacher just gave instructions to read aloud the texts, to let the students find the difficult words and translate those words together, to ask the students to translate the whole text, to ask the students to conclude the texts and to ask the students to do the exercises individually.

\section{Conclusion}

Based on the results of the study, it can be concluded that there was a significant difference on students' reading comprehension achievement of the group of students who were taught by using Cloze reading strategy compared to those who were taught by using the strategy that was usually used by the teacher at the school.

\section{References}

Abrar, M., Mukminin, A., Habibi, A., Asyrafi, F., Makmur, M., \& Marzulina, L. (2018). "If our english isn't a language, what is it?" indonesian EFL student teachers' challenges speaking English. Qualitative Report, 23(1), 129-145.

Astrid, A., Marzulina, L., Erlina, D., Harto, K., Habibi, A., \& Mukminin, A. (2019). Teaching writing to efl student teachers: Teachers' intervention and no teachers' intervention through peer feedback writing techniques. Universal Journal of Educational Research, 7(9), 1901-1908. doi:10.13189/ujer.2019.070908

Astrid, A., Amrina, R. D., Desvitasari, D., Fitriani, U., \& Shahab, A. (2019). The Power of Questioning: Teacher's Questioning Strategies in the EFL Classrooms. IRJE|Indonesian Research Journal in Education|, 3(1), 91-106. Retrieved from https://onlinejournal.unja.ac.id/irje/article/view/6601

Brown, D. (2007). Principles of language learning and teaching. America, US : Longman.

Chatel, S. (2011). Using e-readers and internet resources to support comprehension. Educational Technology and Society, 16(1), 367-379. Retrieved from http://www.SciRp.org/journal/ce.

Cook, F. O. (2001). Academic achievement and relationship with anxiety, self-esteem, optimism, and pessimism in Kuwaiti students. Social Behavior Personality, 33(1), 95-104.

Retrieved from https://www.sbp-journal.com/index.php/sbp/article/view/1382.

Cooper, J. (2000). Motivation and its relationship with reading achievement in an urban middle school. The Journal of Educational Research, 100(4), 81-101. Retrieved from https://doi.org/10.3200/JOER.100.2.81-101.

Crede, M., \& Kuncel, N. (2008). Study habits meta-analysis. Perspectives on Psychological Science In Press, 3(6), 425-453.

Duke, C., \& Pearso. (2001). Motivation and cloze regulation: A comparison of students with learning and behavior problems. Journal of Remedial and Special Education, 19(2), 300309. Retrieved from https://www.researchgate.net/publication/230689260_Motivation_and_ClozeRegulation_A_Comparison_of_Students_with_Learning_and_Behavior_Problems

Erlina, D., Marzulina, L., Astrid, A., Desvitasari, D., Sapriati, R. S., Amrina, R. D., Mukminin, A., Habibi, A. (2019). Linguistic intelligence of undergraduate EFL learners in higher 
education: A case study. Universal Journal of Educational Research, 7(10), 2143-2155. doi:10.13189/ujer.2019.071012

Erlina, D., Desvitasari, D., Marzulina, L., \& Meida Risfina, A. (2020). Students’ Demotivating Factors in English Language Learning at One State Madrasah Tsanawiyah in Palembang, South Sumatera, Indonesia. IRJE |Indonesian Research Journal in Education|, 4(1), 120136. Retrieved from https://online-journal.unja.ac.id/irje/article/view/9024

Fraenkel, J. R., \& Norman E. W. (2012). How to design and evaluate research in education $\left(8^{\text {th }}\right.$ ed.). Boston: McGraw-Hill Higher Education.

Goodman, K. S. (2000). Ken goodman on reading: A common sense look at the nature of language and the science of reading. Portsmouth, NH: Heinemann.

Harmer, J. (2000). The practice of English language teaching (3rd ed.). New York, NY: Pearson Education Limited.

Kaniuka, T. (2010). Reading achievement, attitude toward reading, and reading self esteem of historically low achieving students. Journal of Instructional Psychology, 37(2), 84-88. Retrieved from https://www.researchgate.net/publication/309347646_Reading_achievement_attitude_to ward_reading and_reading_self-esteem_of historically_low_achieving_students.

Komiyama, R. (2009). CAR: A mean for motivating students to read. English Teaching Forum, 47(3), 32-77. Retrieved from http://files.eric.ed.gov/fulltext/EJ923458.pdf.

Lyon, G. R. (2010). Beginning to read: Thinking and learning about print. Cambridge, UK: MIT Press.

Marzulina, L., Erlina, D., Pitaloka, N. L., \& Paramika, F. A. (2019). Looking at the Link between Study Habits and Academic Achievement: The Case of Indonesian EFL Student Teachers. IRJE |Indonesian Research Journal in Education|, 3(1), 57-76. Retrieved from https://online-journal.unja.ac.id/irje/article/view/6507

Marzulina, L., Pitaloka, N. L., Herizal, H., Holandyah, M., Erlina, D., \& Lestari, I. T. (2018). Looking at the Link between Parents' Educational Backgrounds and Students' English Achievement. IRJE |Indonesian Research Journal in Education|, 2(1), 51-60. Retrieved from https://online-journal.unja.ac.id/irje/article/view/4425

Marzulina, L., Mukminin, A., Erlina, D., Astrid, A., Ajriyah, N., Holandiyah, M., \& Habibi, A. (2019). The grammatical awareness of student teachers: The case of an english education study program in indonesia. Universal Journal of Educational Research, 7(9), 18471859. doi:10.13189/ujer.2019.070902

Mather, E. (2002). The relationship between school climate, academic self-concept, and academic achievement. European Journal of Research and Reflection in Educational Science, 62(5), 1697-1717.

Mintz, Z. (2009). Coherence and students' errors: Weaving the threads of discourse. English Teaching Forum, 34(3), 44-54. Retrieved from http://dosfanlib.uic.edu/usia/EUSIA/forum/vols/vol34/no3/p44.htm.

Moenly, C. E. (2009). Reading for understanding: Toward an $R \& D$ program in reading comprehension. Santa Monica, CA: RAND Education.

Mukminin, A., Ali, R. M., \& Ashari, M. J. F. (2015). Voices from within: Student teachers' experiences in english academic writing socialization at one indonesian teacher training program. Qualitative Report, 20(9), 1394-1407.

Mukminin, A., Haryanto, E., Sutarno, S., Sari, S. R., Marzulina, L., Hadiyanto, \& Habibi, A. (2018). Bilingual education policy and indonesian students' learning strategies. 
[Çiftdillilik politikası ve endonezyalı öğrencilerin öğrenme stratejileri] Elementary Education Online, 17(2), 1204-1223.

Mukminin, A., Muazza., Hustarna., \& Sari, S.R. (2015). Stories from the frontlines: In-service teachers' demotivating factors and policy recommendations. International Journal of Academic Research in Education, 1(2), 40-52.

Mukminin, A., Sari, S. R., Haryanto, E., Habibi, A., Hidayat, M., Marzulina, L., Nurullaningsih N., Ikhsan, I. (2019). They can speak English, but they don't want to use it." teaching contents through English in a bilingual school and policy recommendations. Qualitative Report, 24(6), 1258-1274.

Nazurty, Rustam, Priyanto, Nurullaningsih, Pratiwi, A., Sarmandan, Habibi, A., Mukminin, A. (2019). Learning strategies in reading: The case of indonesian language education student teachers. Universal Journal of Educational Research, 7(11), 2536-2543. doi:10.13189/ujer.2019.071133

PIRLS. (2011). International result in literacy. Retrieved from http://litbang.kemdikbud.go.id/index.php/survei-internasional-pirls.

Raymond, K. D. (2002). Smuggling writing: Strategies that get students to write everyday in every content area grade 3-12. Thousand Oaks, CA: Crown Literacy CL.

Rye, E. L. (1999). Intrinsic motivation and cloze reading in human behavior. New York, NY: Plenum.

Richards, J., \& Renandya, W.(2002). Methodology in language teaching an anthology of current practice. New York, NY: Cambridge University Press.

Soma, R., Mukminin, A., \& Noprival. (2015). Toward a Better Preparation of Student Teachers' Reading Skill: the SQ3R Strategy with Authentic and Simplified Texts on Reading Literacy and Vocabulary Mastery. Journal of Education and Learning (Edularn), 9 (2), 125-134.

UNESCO. (2011). Measuring the economic contribution of cultural industries. Canada: UNESCO Institute for Statistics (UIS).

Zuchdi, D. (2007). Strategi meningkatkan kemampuan membaca. Yogyakarta: UNY Press. 